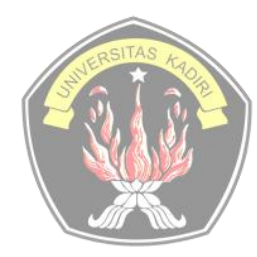

Tersedia online di



\title{
Pengaruh Pelayanan Fiskus dan Sikap Wajib Pajak Terhadap Kepatuhan Wajib Pajak (Wajib Pajak Orang Pribadi Di Kota Bandung Tahun 2016)
}

\author{
N. Heriyah ${ }^{1}$ \\ 1, Universitas Informatika dan Bisnis \\ email: ${ }^{1}$ heryahamoy@gmail.com
}

\section{Artikel History:}

Artikel masuk : 01-08-2020

Artikel revisi : 07-09-2020

Artikel diterima : 26-09-2020

\section{Keywords:}

Taxpayer Compliance;

Fiscal Services;

Taxpayer Attitudes

\begin{abstract}
ABSTRAK
Jumlah wajib pajak dari tahun ke tahun semakin meningkat tetapi masih ada kendala yang dapat menghambat upaya peningkatan rasio pajak, yang menjadi kendala adalah kepatuhan pajak (tax compliance). Beberapa faktor yang dapat mempengaruhi kepatuhan wajib pajak yang diambil dalam penelitian ini adalah pelayanan fiskal dan sikap wajib pajak. Penelitian ini dilakukan untuk menilai tingkat kepatuhan wajib pajak, terutama orang pribadi di kota Bandung dengan menggunakan variabel independen ini. Variabel pelayanan fiskal dan sikap wajib pajak dipilih karena cenderung lebih sesuai dengan wajib pajak orang pribadi dibandingkan dengan variabel lain. Karena kedua variabel tersebut berhubungan langsung dengan bagaimana wajib pajak orang pribadi akan menentukan sikap wajib pajak pada kepatuhan wajib pajak dan wajib pajak orang pribadi dengan otoritas pajak dalam hal ini layanan wajib pajak pada kepatuhan wajib pajak.

Populasi dalam penelitian ini adalah wajib pajak orang pribadi yang berada di Kota Bandung. Berdasarkan data yang diperoleh dari lima Kantor Pajak Pratama di Bandung hingga 2016 tercatat sebanyak 749.929 orang yang merupakan wajib pajak pribadi. Tidak semua wajib pajak perorangan yang efektif tunduk pada aturan yang ada, sehingga pada penelitian yang dilakukan karena jumlah mereka yang besar, oleh karena itu untuk efisiensi waktu dan biaya dilakukan pengambilan sampel. Pengambilan sampel dilakukan pada 400 orang dengan menggunakan metode probability sampling. Metode pengumpulan data primer yang digunakan adalah dengan metode kuesioner, sedangkan teknik analisis data yang digunakan dalam penelitian ini adalah teknik analisis regresi linier berganda. Berdasarkan hasil analisis yang dilakukan maka diperoleh kesimpulan bahwa jasa fiskal dan sikap wajib pajak berpengaruh positif signifikan terhadap kepatuhan wajib pajak baik secara simultan maupun parsial.
\end{abstract}

\section{ABSTRACT}


The number of taxpayers from year to year is increasing but there are still obstacles that can hamper efforts to increase tax ratio, the obstacle is tax compliance (tax compliance). Several factors that can influence taxpayer compliance are taken in this study is fiscal servicesand the attitude of taxpayers. This study was conducted to assess the level of taxpayer compliance, especially private persons in the city of Bandung by using these independent variables. Variables offiscal service and taxpayer attitude are chosen because it tends to be more in line with individual taxpayer compared with other variables. Because the two variables are directly related to how the individual taxpayers will determine the attitudes of the taxpayer on taxpayer compliance and individual taxpayers with the tax authorities in this case the taxpayer service on compliance taxpayer. Population in this research is individual taxpayer residing in Bandung City. Based on data obtained from five Primary Tax Office in Bandung until 2016 was recorded as many as 749,929 people who is an effective personal taxpayer. Not all the effective individual taxpayers are subject to the research because of their huge amounts, therefore for the efficiency of time and costs sampling is taken. Sampling was done on 400 people by using probability sampling method. The primary data collection method used is by questionnaire method, while the data analysis technique used in this research is multiple linear regression analysis technique. Based on the results of the analysis conducted then obtained the conclusion that the fiscal servicesand the attitudes of taxpayers have a significant positive effect on taxpayer compliance either simultaneously or partially.

\section{PENDAHULUAN}

Berdasarkan dari data BPS tahun 2011-2013 menunjukkan bahwa pajak merupakan penyumbang APBN lebih dari 70\%. Direktorat Jendral Pajak (DJP) Tahun 2013, menjelaskan,"Pajak merupakan sumber utama penerimaan Negara". Berdasarkan pernyatan tersebut, maka pemerintah khususnya DJP terus berupaya untuk meningkatkan penerimaan pajak. Upaya yang dilakukan DJP adalah dengan cara ekstensifikasi pajak, yaitu menjaring subjek-subjek pajak baru yang selama ini belum terdaftar sebagai wajib pajak, intensifikasi pajak, yaitu mencari sumber-sumber objek pajak yang belum tergarap dan modernisasi pajak (Hidayat, 2005). Selain dari ketiga upaya tersebut, DJP juga melakukan reformasi perpajakan pertama kali yaitu pada tahun 1983 dengan diberlakukannya self assessment system, dimana wajib pajak diharuskan untuk berperan aktif dalam pemenuhan kewajiban perpajakan, diantaranya adalah dengan menghitung, memperhitungkan, membayar pajak, menyetor, dan 
melaporkan seluruh pajak yang menjadi kewajibannya. Namun demikian dalam pran suan.
lapangan, system pemungutan pajak di Indonesia sulit dijalankan sesuai harapan.

Tabel 1

Rasio Kepatuhan Wajib Pajak Tahun 2011 - 2015

\begin{tabular}{|l|r|r|r|r|r|}
\hline Uraian & \multicolumn{1}{|c|}{$\mathbf{2 0 1 5}$} & $\mathbf{2 0 1 4}$ & $\mathbf{2 0 1 3}$ & $\mathbf{2 0 1 2}$ & $\mathbf{2 0 1 1}$ \\
\hline $\begin{array}{c}\text { WP } \\
\text { Terdaftar }\end{array}$ & $\mathbf{1 9 . 2 2 0 . 4 5}$ & $\mathbf{1 8 . 3 5 7 . 8 3}$ & $\mathbf{1 7 . 7 3 1 . 7 3}$ & $\mathbf{1 7 . 6 5 9 . 2 7 8}$ & $\mathbf{1 9 . 9 1 3 . 9 0}$ \\
\hline WP Badan & 1.167 .507 & 1.166 .036 & 1.141 .797 & 1.026 .388 & 2.450 .655 \\
\hline WP OP & 18.052 .94 & 17.191 .79 & 16.589 .93 & 16.632 .890 & 17.463 .24 \\
& 4 & 7 & 9 & & 9 \\
\hline SPT & $\mathbf{1 1 . 6 7 0 2 4 2}$ & $\mathbf{1 0 . 8 0 7 . 6 2}$ & $\mathbf{1 0 . 7 8 1 . 1 0}$ & $\mathbf{9 . 4 8 2 . 4 8 0}$ & $\mathbf{8 . 9 7 2 . 5 9 7}$ \\
Tahunan PPh & & $\mathbf{4}$ & $\mathbf{3}$ & & \\
\hline WP Badan & 550.127 & 548.676 & 592.373 & 547.659 & 507.844 \\
\hline WP OP & 11.120 .11 & 10.258 .94 & 10.188 .73 & 8.934 .821 & $8.464,753$ \\
& 5 & 8 & 0 & & \\
\hline Rasio & $\mathbf{6 0 , 7 1 \%}$ & $\mathbf{5 8 , 8 7 \%}$ & $\mathbf{6 0 , 8 0 \%}$ & $\mathbf{5 3 , 7 0 \%}$ & $\mathbf{4 5 , 0 5 \%}$ \\
Kepatuhan & & & & & \\
\hline WP Badan & $47,11 \%$ & $47,05 \%$ & $51,88 \%$ & $53,36 \%$ & $20,72 \%$ \\
\hline WP OP & $61,59 \%$ & $59,67 \%$ & $61,72 \%$ & $53,72 \%$ & $48,47 \%$ \\
\hline-
\end{tabular}

Sumber : Data Masterfile ODS, diolah kembali

Selanjutnya SPT Tahunan PPh adalah jumlah SPT Tahunan PPh yang diterima oleh Ditjen Pajak selama masa satu tahun kegiatan. Pada tabel diatas menunjukan bahwa jumlah SPT Tahunan yang diterima oleh Ditjen Pajak mengalami peningkatan dari tahun ke tahun. Kemudian Rasio Kepatuhan merupakan perbandingan antara jumlah SPT Tahunan PPh yang diterima dalam satu tahun pajak tertentu dengan jumlah wajib pajak terdaftar wajib SPT pada awal tahun. 


\section{Tabel 2}

\section{Ratio Kepatuhan Wajib Pajak Orang Pribadi di Kota Bandung}

Tahun 2011 hingga 2015

\begin{tabular}{|c|r|r|r|c|}
\hline Tahun & $\begin{array}{c}\text { Jumlah WP } \\
\text { Terdaftar }\end{array}$ & $\begin{array}{c}\text { Jumlah } \\
\text { Penyampaian } \\
\text { SPT (WP } \\
\text { Efektif) }\end{array}$ & $\begin{array}{c}\text { WP Efektif/Jml } \\
\text { WP Terdaftar }\end{array}$ & $\begin{array}{c}\text { Tingkat } \\
\text { Kepatuhan } \\
\text { Wajib Pajak }\end{array}$ \\
\hline $\mathbf{2 0 1 1}$ & 427.606 & 155.623 & $155.623 / 427.606$ & $36 \%$ \\
\hline $\mathbf{2 0 1 2}$ & 471.076 & 164.814 & $164.814 / 471.076$ & $35 \%$ \\
\hline $\mathbf{2 0 1 3}$ & 511.337 & 161.826 & $161.826 / 511.337$ & $32 \%$ \\
\hline $\mathbf{2 0 1 4}$ & 545.620 & 233.138 & $233.138 / 545.620$ & $42 \%$ \\
\hline $\mathbf{2 0 1 5}$ & 1.004 .650 & 459.276 & $459.276 / 1.004 .650$ & $46 \%$ \\
\hline
\end{tabular}

Sumber : Direktorat Teknologi Informasi Perpajakan, diolah

Kepatuhan wajib pajak merupakan salah satu komponen penting dalam rangka meningkatkan penerimaan pajak. Kepatuhan wajib pajak mencerminkan kesediaan dari individu atau wajib pajak untuk melaksanakan kewajiban perpajakannya. Berbagai dimensi dapat digunakan untuk mengetahui tingkat kepatuhan wajib pajak. Beberapa diantaranya antara lain adanya kewajiban seluruh wajib pajak untuk melaporkan Surat Pemberitahuan (SPT) dan mengungkapkan jumlah penghasilan yang dilaporkan. Sejalan dengan implementasi self assessment diharapkan wajib pajak dapat mencapai suatu tingkat kepatuhan pajak sukarela (voluntary compliance). Berdasarkan kondisi dan latar belakang tersebut, maka penulis tertarik untuk meneliti lebih lanjut mengenai kepatuhan wajib pajak dengan judul penelitian

“ Pengaruh Pelayanan Fiskus Dan Sikap Wajib Pajak Terhadap Kepatuhan Wajib

\section{Pajak"}

\section{TINJAUAN PUSTAKA}

\section{Teori Aksi Beralasan (Theory of Reasoned Action /TRA)}

Ajzen dan Fishbein (1980), dalam "Theoy of reasoned action" atau yang dikenal juga dengan Teori Aksi beralasan menyatakan bahwa niat menentukan seseorang untuk melakukan atau tidak melakukan suatu perilaku. Theory of Reasoned Action adalah suatu teori yang menjelaskan sikap dan perilaku individu dalam melaksanakan suatu kegiatan. Ajzen dan Pengaruh Pelayanan Fiskus dan..... 
Fishbein berpendapat bahwa Theory of Reasoned Action berasal dari kegagalan penelitianpenelitian sebelumnya mengenai teori sikap perilaku tradisional. Berdasarkan Theory of Reasoned Action, perilaku seseorang ditentukan oleh tujuan perilaku untuk melakukannya

\section{Teori Atribusi (Atribution Theory)}

Kepatuhan Wajib pajak terkait dengan sikap wajib pajak dalam membuat penilaian terhadap pajak itu sendiri. Dalam teori atribusi persepsi seseorang untuk membuat penilaian mengenai orang lain sangat dipengaruhi oleh kondisi internal maupun kondisi eksternal orang tersebut. Teori atribusi (attribution theory) sangat relevan untuk menerangkan maksud tersebut di atas. Pada dasarnya, teori atribusi menyatakan bahwa bila individu-individu mengamati perilaku seseorang, maka mereka mencoba untuk menentukan apakah perilaku itu ditimbulkan secara internal ataukah secara eksternal (Robbins, 2009:129)

\section{Kepatuhan Wajib Pajak (Tax Compliance)}

Menurut Norman D. Nowak (Zain, 2007:31), kepatuhan wajib pajak memiliki pengertian yaitu :"Suatu iklim kepatuhan dan kesadaran pemenuhan kewajiban perpajakan, tercermin dalam situasi di mana :

1. Wajib pajak paham atau berusaha untuk memahami semua ketentuan peraturan perundangundangan perpajakan.

2. Mengisi formulir pajak dengan lengkap dan jelas

3. Menghitung jumlah pajak yang terutang dengan benar

4. Membayar pajak yang terutang tepat pada waktunya"

\section{Pelayanan Fiskus Terhadap Kepatuhan Wajib Pajak}

Menurut Kottler dan Keller (2008:42) mendefinisikan layanan sebagai tindakan atau kegiatan yang ditawarkan oleh satu pihak kepada pihak lain yang pada dasarnya tidak berwujud yang dapat menciptakan nilai dan memberikan manfaat kepada pelanggan pada waktu dan tempat tertentu dengan menimbulkan perubahan keinginan atau kepentingan penerimaan layanan. Menurut Kottler dan Keller (2008:54), terdapat lima dimensi yang digunakan sebagai indikator atau ukuran kualitas pelayanan. Adapun lima dimensi kualitas layanan tersebut, adalah:

1. Keandalan (reliability),

2. Responsive / daya tanggap (responsiveness),

3. Kepastian / jaminan (assurance),

4. Empati (empathy), 
5. Berwujud/bukti fisik (tangible),

\section{Kerangka Pemikiran}

Dalam penelitian ini yang dimaksudkan dengan pelayanan fiscus dan sikap wajib pajak tersebut diduga akan berpengaruh terhadap kepatuhan wajib pajak dalam memenuhi kewajiban membayar pajak.

\section{Gambar 1}

KerangkaPemikiran Teoritis

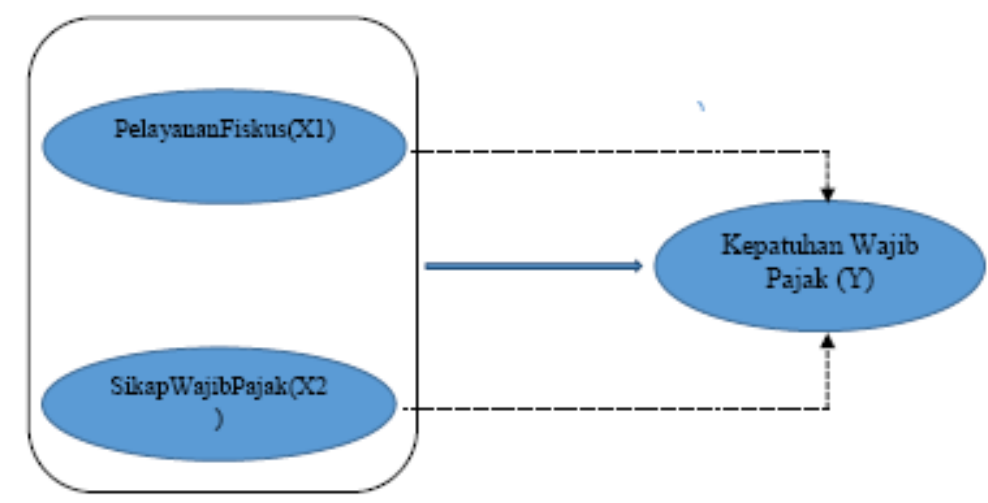

Keterangan : Pengaruh secara simultan

Pengaruh secara parsial

\section{Hipotesis}

Fiskus atau petugas pajak yang bertanggungjawab dan mendayagunakan sumber daya manusia sangat dibutuhkan guna meningkatkan kepatuhan wajib pajak. Secara empiris hal ini telah dibuktikan oleh Loekman Sutrisno (1994) yang menemukan bahwa terdapat hubungan antara pembayaran pajak dengan mutu pelayanan publik untuk wajib pajak. Fiskus atau petugas pajak diharapkan memiliki kompetensi yang baik dalam arti memiliki keahlian (skill), pengetahuan (knowledge), dan pengalaman (experience) dalam hal kebijakan perpajakan, administrasi pajak, dan perundang-undangan perpajakan. Selain itu fiskus atau petugas pajak juga harus memiliki motovasi yang tinggi sebagai pelayan publik. Dari uraian tersebut, dapat dikatakan bahwa mutu pelayanan petugas pajak atau fiskus diduga akan berpengaruh terhadap kepatuhan wajib pajak di dalam membayar pajak. Berdasarkan hal tersebut maka dapat dirumuskan hipotesis sebagai berikut:

\section{H1 : Pelayanan Fiskus berpengaruh terhadap kepatuhan wajib pajak}


Sikap pada tingkah laku atau perbuatan manusia dalam kehidupan manusia sehari-hari, dapat pula dikatakan sikap merupakan salah satu aspek yang mempengaruhi pola berfikir individu dalam kesehariannya terutama dalam proses pengambilan keputusan. Pada saat sikap telah terbentuk, maka sikap akan menentukan cara-cara berperilaku terhadap objek tertentu. Hal ini menunjukkan betapa pentingnya peran dari sikap tersebut. Oleh sebab itu sikap atau pandangan wajib pajak diduga akan berpengaruh terhadap tingkat kepatuhan wajib pajak dalam memenuhi kewajibannya dalam membayar pajak. Berdasarkan hal tersebut maka dirumuskan hipotesis sebagai berikut:

\section{H2 : Sikap wajib pajak berpengaruh terhadap kepatuhan wajib pajak}

\section{METODE PENELITIAN}

\section{Objek Penelitian}

Menurut Sugiyono (2017:13) yang dimaksud dengan objek penelitian adalah : "Objek penelitian adalah sasaran ilmiah untuk mendapatkan data dengan tujuan dan kegunaan tertentu tentang sesuatu hal objektif, valid, dan reliabel tentang suatu hal (variabel tertentu)" Objek penelitian ini akan dilakukan pada wajib pajak orang pribadi (WPOP) yang berada di KPP Pratama Bandung yang meliputi lima Kantor Pelayanan Pajak (KPP), yaitu :

1. KPP Pratama Cibeuying, yang berkedudukan di Jl. Purnawarman No.21 Bandung

2. KPP Pratama Karees, yang berkedudukan di Jl. Ibrahim Aji No. 372 Bandung

3. KPP Pratama Cicadas, yang berkedudukan di Jl. Soekarno Hatta No. 781 Bandung

4. KPP Pratama Tegalega, yang berkedudukan di Jl. Soekarno Hatta No. 216 Bandung

5. KPP Pratama Bojonegara, yang berkedudukan di Jl. Prof. Sutami No. 1 Bandung

$$
\mathrm{n}=\frac{N}{1+N(e)^{2}}
$$

Berdasarkan data dari KPP yang ada di Kota Bandung, hingga tahun 2016 tercatat sebanyak 749.929 wajib pajak orang pribadi yang merupakan WP OP efektif. Maka jumlah sampel untuk penelitian dengan margin of error sebesar 5\% adalah :

Sehingga jumlah sampel yang diambil dalam penelitian ini adalah sebanyak 400 Wajib Pajak Orang Pribadi. Sampel yang berjumlah 400 tersebut akan didistribusikan pada lima KPP secara proporsional. Perhitungan jumlah sampel yang diambil untuk setiap KPP berdasarkan perhitungan sampling adalah sebagai berikut : 


\section{Perhitungan PengambilanSampel Untuk Setiap KPP}

\begin{tabular}{|l|c|c|c|}
\hline \multicolumn{1}{|c|}{ Nama KPP } & $\begin{array}{c}\text { WP OP Efeltif } \\
\text { (Populasi) }\end{array}$ & Prosentase & $\begin{array}{c}\text { Target Populasi } \\
\text { (Jumlah Sampel) }\end{array}$ \\
\hline KPP Cibeuying & 149.811 & $19,97 \%$ & 80 \\
\hline KPP Karees & 169.696 & $\mathbf{2 2 , 6 3} \%$ & 90 \\
\hline KPP Cicadas & 153.908 & $\mathbf{2 0 , 5 2} \%$ & $\mathbf{8 2}$ \\
\hline KPP Tegalega & 135.926 & $18,13 \%$ & 73 \\
\hline KPP Bojonegara & 140.588 & $18,75 \%$ & 75 \\
\hline Jumlah & 749.929 & $100 \%$ & 400 \\
\hline \multicolumn{2}{|l|}{ Sumber : Bagian Unum KPP di Kota Bandung, diolah oleh peneliti. } \\
\hline
\end{tabular}

\section{Analisis Data}

Penelitian ini dilakukan dengan menggunakan teknik analisis regresi berganda untuk mengolah dan membahas data yang telah diperoleh dan untuk menguji hipotesis yang diajukan. Teknik analisis regresi dipilih untuk digunakan pada penelitian ini karena teknik analisis berganda dapat menyimpulkan secara langsung mengenai pengaruh masing-masing variabel bebas yang digunakan secara parsial maupun simultan atau bersama-sama. Adapun model regresi yang digunakan adalah sebagai berikut :

Patuh $\quad=\alpha+\beta 1$ Pelayanan Fiskus $+\beta 2$ Sikap Wajib Pajak $+e$

Dimana :

Patuh $\quad=$ Kepatuhan WP

$\alpha \quad=$ Konstanta

$\beta 1, \beta 2, \quad=$ Koefisien regresi

Pelayanan Fiskus $\quad=$ Pelayanan Fiskus Terhadap Kepatuhan WP

Sikap $\quad$ =Sikap WP Terhadap Kepatuhan WP

e $\quad$ Residual

\section{Uji Validitas}

Uji validitas instrumen dilakukan untuk mengetahui instrumen penelitian mampu mencerminkan isi sesuai hal dan sifat yang diukur, artinya setiap butir instrumen telah benarbenar menggambarkan keseluruhan isi yang menjadi dasar penyusunan instrumen. Menurut Sugiyono (2017:134) analisis faktor dilakukan dengan cara mengkorelasikan tiap faktor tersebut dan besarnya 0,3 ke atas maka faktor tersebut merupakan construct yang kuat. 


\section{Uji Reliabilitas}

Uji reliabilitas dilakukan untuk mengetahui apakah alat pengumpul data menunjukkan tingkat ketepatan, keakuratan, kestabilan, atau konsistensi alat tersebut dalam mengungkapkan gejala tertentu dari sekelompok individu walaupun dilakukan pada waktu yang berbeda. Dalam penelitian ini pengukuran reliabilitas kuesioner melalui uji statistik Alpha-Cronbach dengan program SPSS (Statistical Package for Sosial Sciences) for Windows. Suatu konstruk atau variabel dapat dikatakan reliabel jika memberikan nilai Alpha-Cronbach>0,70 pada hasil pengujian.

\section{Uji Normalitas}

Uji statistik regresi dan korelasi perlu dilakukan pengujian normalitas data, hal ini dilakukan untuk mengetahui apakah sampel yang digunakan dalam penelitian ini berasal dari populasi yang berdistribusi normal atau tidak. Uji normalitas yang digunakan dalam penelitian ini adalah Kolmogorov-Smirnov Test yang nantinya akan diolah dengan bantuan SPSS 20.0 for windows, kemudian alat uji statistik parametric dapat digunakanbila asumsi data sampel berdistribusi normal terpenuhi. Dasar pengambilan keputusan bisa dilakukan berdasarkan probabilitas (AsymtotikSignificance), yaitu (Imam Ghozali, 2016:100) :

a. Jika Probabilitas > 0,05 maka distribusi dari populasi adalah normal

b. Jika Probabilitas < 0,05 maka populasi tidak berdistribusi normal

\section{Uji Multikolinieritas}

Uji multikolinieritas bertujuan untuk menguji apakah model regresi ditemukan adanya korelasi antar variabel bebas (independen). Multikolinieritas adalah suatu hubungan linier yang sempurna (mendekati sempurna) antara beberapa atau semua variabel bebas (Imam Ghozali, 2016:105).

\section{Uji Heterokedastisitas}

Menurut Imam Ghozali (2016:139), uji heterokedastisitas bertujuan menguji apakah model regresi terjadi ketidaksamaan variance dari residual satu pengamatan ke pengamatan lain. Jika variance dari residual satu pengamatan ke pengamatan lain tetap, maka disebut Homoskedastisitas dan jika berbeda disebut Heterokedastisitas. Persamaan regresi yang baik jika tidak terjadi heterokedastisitas. Uji heterokedastisitas ini bertujuan untuk mengetahui apakah dalam model regresi terjadi kesalahan atau ketidaksamaan variance dari residual pada model yang sedang diamati dari satu observasi ke observasi yang lain. 


\section{Analisis Koefisien Korelasi Berganda}

Analisis koefisien korelasi berganda digunakan untuk mengukur satu hubungan yang terjadi antara variabel bebas dengan variabel terikat.

\section{Uji Simultan (Uji F)}

Analisis pada Uji F bertujuan untuk mengetahui pengaruh secara simultan atau bersama-sama antar variabel independen terhadap variabel dependen. Pengaruh tersebut memiliki tingkat signifikansi pada alpha 5\%.

\section{Uji Parsial (Uji t)}

Uji statistik t adalah untuk menguji keberhasilan koefisien regresi secara parsial. Pengujian ini dilakukan untuk mengetahui apakah variabel bebas (X) secara tunggal berpengaruh terhadap variabel terikat (Y) dengan membandingkan antara nilai thitung masing-masing variabel bebas dengan nilai $t$ tabel dengan derajat kesalahan $5 \%(\alpha=0,05)$.

\section{HASIL \& PEMBAHASAN}

\section{Gambaran Objek Penelitian}

Objek penelitian dalam penelitian ini adalah wajib pajak orang pribadi yang berada di Kantor Pelayanan Pajak Pratama Bandung yang meliputi lima Kantor Pelayanan Pajak yang selanjutnya disebut populasi. Jumlah populasi pada penelitian ini adalah berjumlah 749.929 wajib pajak orang pribadi yang berasal dari lima Kantor Pelayanan Pajak. Dari populasi yang berjumlah 749.929 wajib pajak orang pribadi diperoleh target populasi yang selanjutnya disebut sampel yang berjumlah 400 wajib pajak orang pribadi yang masing-masing KPP terdiri dari KPP Pratama Bandung Cibeuying berjumlah 80 wajib pajak orang pribadi, KPP Pratama Bandung Karees berjumlah 90 wajib pajak orang pribadi, KPP Pratama Bandung Cicadas berjumlah 82 wajib pajak orang pribadi, KPP Pratama Bandung Tegalega berjumlah 73 wajib pajak orang pribadi, dan KPP Pratama Bandung Bojonegara berjumlah 75 wajib pajak orang pribadi.

\section{Variabel Pelayanan Fiskus}

Melalui jumlah skor tanggapan dari 5 pernyataan yang diajukan mengenai variabel Pelayanan Fiskus, maka dapat diketahui bahwa tanggapan responden mengenaiPelayanan Fiskus termasuk dalam kategori “baik”.Berdasarkan hasil perhitungan maka dapat diartikan bahwa wajib pajak 
orang pribadi telah merasakan pelayanan yang cukup baik dari pelayan fiskus atau aparat perpajakan. Pelayanan fiskus selalu berusaha untuk memenuhi semua kebutuhan dan keperluan yang dibutuhkan oleh wajib pajak khususnya orang pribadi.

\section{Variabel Sikap Wajib Pajak}

Melalui jumlah skor tanggapan dari 5 pernyataan yang diajukan mengenai variabel Pelayanan Fiskus, maka dapat diketahui bahwa tanggapan responden mengenaiPelayanan Fiskus termasuk dalam kategori "baik".Berdasarkan hasil perhitungan maka dapat diartikan bahwa wajib pajak orang pribadi telah merasakan pelayanan yang cukup baik dari pelayan fiskus atau aparat perpajakan. Pelayanan fiskus selalu berusaha untuk memenuhi semua kebutuhan dan keperluan yang dibutuhkan oleh wajib pajak khususnya orang pribadi. Melalui jumlah skor tanggapan dari 8 pernyataan yang diajukan mengenai variabel Sikap Wajib Pajak, maka dapat diketahui bahwa tanggapan responden mengenaiSikap Wajib Pajak termasuk dalam kategori "baik".

Namun demikian dapat dilihat bahwa skor terendah yaitu 1.363 yang diperoleh dari penyataan kuesioner penelitian yaitu wajib pajak merasa yakin bahwa pajak yang sudah dibayar benarbenar digunakan untuk pembangunan. Berdasarkan hasil dari perhitungan diatas maka dapat diartikan bahwa wajib pajak orang pribadi di Kota Bandung merasa kurang yakin bahwa pajak yang sudah dibayar memang benar-benar telah digunakan untuk pembangunan, meskipun wajib pajak orang pribadi tersebut telah melakukan kewajibannya dengan membayar pajak. Selanjutnya dapat dilihat bahwa skor tertinggi yaitu sebesar 1.641 yang diperoleh dari kuesioner penelitian yaitu pemanfaatan pajak yang dirasakan tidak transparan. Berdasarkan hasil perhitungan di atas maka dapat diartikan bahwa wajib pajak orang pribadi di Kota Bandung pada umumnya merasakan bahwa pemanfaatan dari pajak yang dirasakan tidak transparan. Pajak yang merupakan pendapatan yang berasal dari wajib pajak hendaknya dapat diketahui oleh wajib pajak pemanfaatannya secara transpar

\section{Variabel Kepatuhan Wajib Pajak}

Melalui jumlah skor tanggapan dari 4 pernyataan yang diajukan mengenai variabel Kepatuhan Wajib Pajak, maka dapat diketahui bahwa tanggapan responden mengenaiKepatuhan Wajib Pajak termasuk dalam kategori "baik".Berdasarkan hasil perhitungan di atas maka dapat diartikan bahwa wajib pajak orang pribadi selalu berusaha untuk membayar pajak atau memenuhi kewajiban perpajakannya tepat pada waktunya. Salah satu penyebab dari tingginya skor perolehan pada pernyataan ini agar wajib pajak terhindar dari pengenaan sanksi perpajakan. 


\section{SIMPULAN \& SARAN}

Berdasarkan pembahasan hasil penelitanpada bab sebelumnya, hasil pengolahan data dan uji hipotesis yang telah dilakukan maka penulis mengambil kesimpulan sebagai berikut :

\section{Simpulan}

1. Pelayanan fiskus dan sikap wajib pajak secara bersama-sama dapat meningkatkan kepatuhan wajib pajak. Secara empiris hasil penelitian membuktikan bahwa penerapan sanksi perpajakan merupakan salah satu variabel yang memiliki pengaruh terbesar terhadap kepatuhan wajib pajak, selanjutnya untuk pelayanan fiskus yang prima dan memenuhi kategori keandalan (reliability), responsive (responsiviness), kepastian (assurance), empaty (empathy), berwujud (tangible) akan memberikan pengaruh positif kepada wajib pajak dalam melaksanakan kewajiban perpajakannya. Semakin baik pelayanan yang diterima maka wajib pajak akan semakin patuh.

\section{Saran}

Secara empiris hasil penelitian membuktikan bahwa semakin tinggi tingkat kepercayaan dan keyakinan wajib pajak kepada aparat pajak maka akan semakin tinggi tingkat kepatuhan wajib pajak. Secara empiris hasil penelitian membuktikan bahwa semakin baik kualitas pelayanan fiskus atau kualitas pelayanan perpajakan maka semakin tinggi tingkat kepatuhan wajib pajak, demikian pula sebaliknya apabila semakin tidak baik atau rendahnya kualitas pelayanan fiskus atau pelayanan perpajakan maka semakin rendah pula tingkat kepatuhan wajib pajak.

\section{DAFTAR PUSTAKA}

Arikunto. Suharsimi, 2010, Prosedur Penelitian Suatu Pendekatan Praktek, Edisi Revisi

VII, Jakarta : Rineka Cipta

Ajzen, L., \& Fishbein, M,. 1980, TheTheory Of Planned Behavior dalam J. Kuhl\&Beckman, Eds., Action-control :From Cognition to Behavior, Springer, Heidelberg, p.11-39

Ardyanto, Arif Angga Dan Nanik Sri Utaminingsih, 2014, Pengaruh Sanksi Pajak Dan Pelayanan Aaparat Pajak Terhadap Kepatuhan Wajib Pajak Dengan Preferensi Risiko Sebagai Variabel Moderasi, Accounting Analysis Journal, Volume 3, Nomer 2

Bandura, A.,1977, "Sosial Learning Theory”, Englewood Cliffs, Prentitice Hall, New Jersey, 1996

Badan Pusat Statistik, Realisasi Penerimaan Pajak Negara2011-2013, Note:(http://www.bps.go.id diakses tgl 24 November 2016)

Chaidir Ali, 1993, Hukum Pajak Elementer, PT. Eresco 
Darussalam, 2010, Pemerintah Diminta Tingkatkan Kepatuhan Wajib Pajak, Note: (www:http://www.tempo.com diakses November 2010)

Darussalam, 2012, Pajak Dibayar, Sanksi Pidana Tak Digunakan, Note:(www..pajak.go.id, diakses Pada 15 April 2012)

Darussalam, 2013, Rendahnya Kesadaran Pajak, Diakses pada Suara Pembaharuan

Direktorat Jenderal Pajak, Laporan Tahunan, 2014, Note:(www.pajak.co.id), Kementerian Keuangan Republik Indonesia

Direktorat Jenderal Pajak, Refleksi Tingkat Kepatuhan Wajib Pajak,Berita Pajak, No. 1488/Tahun XXXV/23 Maret 2016, Note:.(www.pajak.go.id)

Devano, Sony dan Siti Kurnia Rahayu, 2006, Perpajakan, Konsep, Teori, dan Isu, Jakarta : Kencana Prenada Media Group.

Fuadi, Arabella Oentari dan Yeni Mangonting, 2013, Pengaruh Kualitas Pelayanan Petugas Pajak, Sanksi Perpajakan dan Biaya Kepatuhan Pajak Terhadap Kepatuhan Wajib Pajak UMKM, Jurnal Tax and Accounting Review, Vol I.Nomor I, hal. 35-42.

Fraternesi, 2001, Studi Empiris Tentang Pengaruh Faktor-Faktor Yang Melekat Pada Wajib Pajak Terhadap Keberhasilan Penerimaan Pajak Bumi dan Bangunan di Kota Bengkulu, Tesis Program Pasca Sarjana MagisterManajemen Universitas Diponegoro.

Ghozali, Imam, 2016, Desain Penelitian Kuantitatif \& Kualitatif, Semarang : Yoga Pratama

Hardika, N. Sentosa, 2006, Pengaruh Lingkungan Dan Moral Wajib Pajak Terhadap Sikap Dan Kepatuhan Wajib Pajak Pada Hotel Berbintang Propinsi Bali, Disertasi, Universitas Airlangga, Surabaya.

Hidayat, Nur, 2005, Upaya Mengoptimalkan Penerimaan Pajak, Jurnal Ekonomi Dan Bisnis Terapan, Volume 1. Nomer 2

Hutagaol, John, 2007, "Strategi Meningkatkan Kepatuhan Wajib Pajak”, Jurnal Akuntabilitas, Volume 6, Nomer 2, Maret 2007, hal. 186-193.

Inasius, Fani, 2015, Tax Compliance of Small Medium Enterprises in Indonesia, Vol 7, Nomor 1,ISSN:1944-592X(print), ISSN: 2157-0175(online), p. 67-73

Ikhsan, Budi R, 2007, Kajian Terhadap Faktor-Faktor Yang Mempengaruhi Kepatuhan Wajib Pajak, Journal Akuntansi, Manajemen Bisnis Dan Sektor Publik (JAMBSP), ISSN 18299857, p.288-310

Kottler, Philip dan Keller, Kevin Lane, 2008, Manajemen Pemasaran : PT Macanan Jaya Cemerlang.

Kiryanto, 2000, "Analisis Pengaruh Penerapan Struktur Pengendalian Intern Terhadap Kepatuhan Wajib Pajak bada Dalam Memenuhi Kewajiban Pajak Penghasilannya," Jurnal EKOBIS, Volume 1 Nomer 1, p. 41-52. 
La Midjan, 1994, Pengaruh Budaya Terhadap Sikap Pimpinan Puncak dan Kepala Bagian Akuntansi Perusahaan Go Public, Tesis Program PascaSarjana Magister Manajemen Universitas Padjajaran Bandung.

Loudon, David L., and Della Bitta, Albert J., 1988, Consumer Behavior: conceps and applications, $3^{\text {rd }}$ Edition, McGraw-Hill, New York

Mardiasmo, 2016, Perpajakan, Edisi Revisi, Yogyakarta : Andi Offset

Marini. Jesica, 2012, "Pengaruh Sistem Administrasi Perpajakan Modern dan Kualitas Pelayanan Terhadap Kepatuhan Wajib Pajak (Survey Pada Kantor Pelayanan Pajak Pratama Bandung Karees"

Nasucha, Chaizi, 2003, Pengaruh Reformasi Administrasi Perpajakan Terhadap Kepatuhan Wajib Pajak, Disertasi Doktor PPs UNPAD, Bandung

Nowak, Norman D., 1989, Tax Administration in Theory and Practice, Preager

Publisher, London.

Narimawati. Umi, Sri Dewi A., 2010, Penulisan Karya Ilmiah, Bekasi : Penerbit Genesis

Nugroho, Agus Jatmiko, 2010, Pengaruh Sikap Wajib Pajak Pada Pelaksanaan Sanksi Denda,

Pelayanan Fiskus, Dan Kesadaran Perpajakan Terhadap Kepatuhan Wajib Pajak, Tesis Universitas Dipenogoro, Semarang.

Panggabean, Miando Sahala L., 2002, Self Assesment, Fiskus, dan Kepatuhan Wajib Pajak, Berita Pajak, No. 1462/Tahun XXXIV, p. 31-33

Paramartha. I.Putu. Indra Pradnya, 2016, Pengaruh Kualitas Pelayanan Pengetahuan, Dan Sanksi Perpajakan Pada Kepatuhan Wajib Pajak, E-Jurnal Akuntansi ISSN:2302-8556 Volume 15: 641-666

Prasentiantono. A. Tony, 1994, Kebijakan Ekonomi Publik, Jakarta : Gramedia Pustaka Utama Pramushinta dan Baldic Siregar, 2011, Pengaruh Layanan Fiskus Dan Pelaksanaan Sunset Policy Terhadap Kepatuhan Wajib Pajak Dalam Upaya Peningkatan Pajak,Jurnal Ekonomi Bisnis (JEB), ISSN : 1978-3116 Volume 5 Nomor 2

Robbins, Stephen P.- Jugge, Timothy A, 2009, Perilaku Organisasi- Organizaion Behavior Aplikasi, Edisi 12 Bahasa Indonesia, Jakarta : Salemba Empat

Riduwan, 2014, Metode Dan Teknik Menyusun Tesis, Bandung: Alfabeta

Rajiman, 2014, Faktor-Faktor Yang Mempengaruhi Kepatuhan Wajib Pajak Di Surabaya. eJournal Kewirausahaan, Volume 2 Nomor 1.E-ISSN 2334-1804

Sugiyono, 2017, Metode Penelitian Kuantitatif, Kualitatif, dan R\&D, Bandung : Alfabeta

Sekaran, Uma, 2013, Research Methods for Business: Metodologi Penelitian Untuk Bisnis, Edisi 6, Jakarta : Salemba Empat.

Sujarweni, V.Wiranta, 2014, Metodologi Penelitian, Yogyakarta : Pustaka Baru Press.

Saefudin, Azwar, 2010, Reliabitas dan Validitas, Yogyakarta: Pustaka Pelajar

Simanjuntak. Timbul H.-Imam Mukhlis, 2014, Dimensi Ekonomi Perpajakan Dalam Pembangunan Ekonomi : Penebarplus+.

Suyanto, 2012, Pengaruh Pelayanan Fiskus dan Tingkat Kesadaran Wajib Pajak, Terhadap Perilaku Penghindaran Pajak, Kepatuhan Wajib Pajak Sebagai Variabel Pemoderasi., ISSN: 1412-5366 
Suyatmin, 2004, Pengaruh Sikap Wajib Pajak Terhadap Kepatuhan Wajib Pajak Dalam Pembayaran Pajak Bumi dan Bangunan : Studi Empiris di Wilayah KP PBB Surakarta, Tesis Program Pasca Sarjana Magister Sains AkuntansiUniversitas Dipenogoro.

Sulud Kahono, 2003, Pengaruh Sikap Wajib Pajak Terhadap Kepatuhan Wajib Pajak Dalam Pembayaran Pajak Bumi dan Bangunan : Studi Empiris di Wilayah KP PBB Semarang, Tesis Program Pasca Sarjana Magister SainsAkuntansi Universitas Diponegoro

Solich Jamin, 2001, Analisis Kepatuhan Wajib Pajak Sebelum dan Selama Krisis Ekonomi Pada KPP di Wilayah Jawa Tengah dan DI Yogyakarta, TesisProgram Pasca Sarjana Magister Sains Akuntansi Universitas Diponegoro.

Tika Wulandari dan Suyanto, 2014, Pengaruh Pengetahuan Perpajakan, Tingkat Pendidikan, dan Sanksi Administrasi Terhadap Kepatuhan Wajib Pajak Dalam Melakukan Pembayaran Pajak Bumi dan Bangunan, Jurnal Akuntansi, Volume 2 Nomer 2, ISSN:2540-9646

Titik Aryati, 2012, Analisis Faktor-Faktor Yang Mempengaruhi Tingkat Kepatuhan Wajib Pajak Badan., Media Indonesia dan Manajemen, Volume 25, No. 1 ISSN: 0854-1442

Tim Redaksi Ortax, 2017, Undang-Undang Perpajakan, Jakarta : Observation and Research of Taxation

Ussahawanichakit, Phapruke, 2008, Effect of Organizational Learning Culture on Service Quality and Performace of Thai Accounting Firms, International Journal Business Research.

Waluyo, 2014, Perpajakan Indonesia, Jakarta : Salemba Empat.

Yadnyana, I Ketut, 2009, Pengaruh Moral Dan Sikap Wajib Pajak Pada Kepatuhan Wajib Pajak Koperasi Di Kota Denpasar, Fakultas Ekonomi Universitas Udayana, Denpasar.

Zain, Mohammad, 2007, Manajemen Perpajakan, Jakarta : Salemba Empat. 